\title{
Sub-phenotyping of juvenile dermatomyositis: can it assist clinical decisions?
}

\author{
Shireena A. Yasin ${ }^{1 *}$, Katie Arnold ${ }^{1}$, Erdal Sag ${ }^{1}$, Sarah Tansley², Elena Moraitis ${ }^{1}$, Thomas S. Jacques ${ }^{3}$, \\ Janice L. Holton ${ }^{4}$, Catherine Owens ${ }^{5}$, Neil McHugh ${ }^{2}$, Clarissa Pilkington ${ }^{6}$, Lucy R Wedderburn', \\ The UK Juvenile Dermatomyositis Research Group
}

From 21st European Pediatric Rheumatology (PReS) Congress

Belgrade, Serbia. 17-21 September 2014

\section{Introduction}

Juvenile Dermatomyositis (JDM) is a rare serious disease (affecting 2-3 million children/year) presenting with rash and proximal muscle weakness. Serious complications can include calcinosis, GI ulceration, interstitial lung disease (ILD) and even death. It is becoming clear that JDM is a heterogeneous condition. Dividing JDM into sub-phenotypes would allow better prediction of disease severity and more targeted treatments. We have identified novel auto-antibodies in subtypes of JDM that may correlate with specific phenotypes.

\section{Objectives}

To define clinical \& pathological phenotypes of patients with JDM who have antibodies to Melanoma Differentiation-Associated protein 5 (MDA-5).

\section{Methods \\ Patients}

Patients were included from the Juvenile Dermatomyositis Cohort and Biomarker Study, a multi-centre study including 13 centres from across the UK. The study collects longitudinal clinical and serological data from patients with idiopathic inflammatory myopathies (IIM) of which $85 \%$ are diagnosed with JDM or JDM overlap features (currently $n=446$ patients). Clinical data collected included presence of clinical features, treatment, physicians global assessment and muscle strength assessments including the Childhood Muscle Assessment Score (CMAS).

'Infection Inflammation and Rheumatology Section, Institute of Child Health, UCL, London, UK

Full list of author information is available at the end of the article

\section{Autoantibodies}

Plasma or serum, available for 285 patients, were screened for the presence of autoantibodies by immunoprecipitation and confirmed by ELISA using recombinant MDA-5 protein.

\section{Muscle biopsies}

Muscle biopsies were stained and scored using the JDM Muscle biopsy score tool as described $(1,2)$.The validated muscle biopsy score tool measures severity of muscle pathology across 4 domains and with a separate visual assessment score (0-10).

\section{Results}

Autoantibody screening identified the presence of MDA-5 antibodies in $7.4 \%$ of patients $(21 / 285$ cases $)$. MDA-5 positive patients had significantly increased incidence of ulceration $(\mathrm{p}=0.03)$, arthritis $(\mathrm{p}<0.01)$ and lung disease, yet had less severe muscle involvement, measured by CMAS score ( $\mathrm{p}=0.03)$, than MDA- 5 negative patients. In addition, median muscle biopsy scores for the MDA-5+ve patients were significantly lower than the MDA-5-ve patients $(\mathrm{p}<0.005)$ suggesting a less severe muscle pathology.

\section{Conclusion}

JDM is a heterogeneous condition with sub-phenotypes defined by autoantibody status, clinical features and muscle pathology. Identification and classification of sub-phenotypes could be used to predict disease course and severity. In the future, JDM specific autoantibodies could be used as biomarkers allowing for stratified approaches to treatment.

\section{Disclosure of interest}

None declared. 


\section{Authors' details}

'Infection Inflammation and Rheumatology Section, Institute of Child Health, UCL, London, UK. ${ }^{2}$ Rheumatology, Royal National Hospital for Rheumatic Diseases, Bath, UK. ${ }^{3}$ Birth Defects Research Centre, Institute of Child Health, UCL, UK. ${ }^{4}$ Molecular Neuroscience, MRC centre for neuromuscular diseases, Institute of Neurology, UCL, UK. ${ }^{5}$ Cardiothoracic Radiology, Great Ormond Street Hospital, London, UK. ${ }^{6}$ Rheumatology, Great Ormond Street Hospital, London, UK.

Published: 17 September 2014

doi:10.1186/1546-0096-12-S1-018

Cite this article as: Yasin et al:: Sub-phenotyping of juvenile

dermatomyositis: can it assist clinical decisions? Pediatric Rheumatology 2014 12(Suppl 1):018.

Submit your next manuscript to BioMed Central and take full advantage of:

- Convenient online submission

- Thorough peer review

- No space constraints or color figure charges

- Immediate publication on acceptance

- Inclusion in PubMed, CAS, Scopus and Google Scholar

- Research which is freely available for redistribution

Submit your manuscript at www.biomedcentral.com/submit 